\title{
MANDATORY LICENSE LICENSE AS ONE OF THE OBJECTIVES OF LIMITATION OF PATENT EXCLUSIVE RIGHTS
}

\author{
DEVI CANTIKA \\ 155100018 \\ Faculty of Computer, 448757182 \\ devicantika.student@umitra.ac.id
}

\begin{abstract}
A patent is a special right granted based on the law by the government to a person or legal entity that has an invention in the field of technology. Patents as ownership regimes with exclusive rights are not limitless. Countries may regulate exceptions to the exclusive rights covered by the patent. Provided that the exception is not without legitimate reasons contrary to the normal exploitation of the patent and does not harm the reasonable interests of the Patent Holder, and continues to take into account the interests of the third party. One form of limiting exclusive patent rights is the rule regarding compulsory license.
\end{abstract}

Keywords: patents, exclusive rights, compulsory licenses 


\section{A. INTRODUCTION}

In general, in Black's Law Dictionary, this license is interpreted as: A personal privilege to do certain acts or series of acts and the permission by competent authority to do which, without such permissions, would be illegal, a trepass, a tort, or othewise would not allowable (Henry Campbell Black, 1996;1279). So that means a license is a form of right to do one or a series of actions or actions given by those in authority in the form of permission. In the absence of these permits, the act or act constitutes an illegal act which is illegal.

If we try to explore further, the license is defined in Black's Law Dictionary, where it says that Licensing is:

The sale of licenses permits the use of patents, trademarks or the technology to another firm (Henry Campbell Black, 1996; 1280).

We can draw the conclusion that the meaning of licenses indirectly has shifted towards "selling" licenses (privileges) to use patents, rights to brands (especially trademarks) or technology (excluding patent protection $=$

trade secrets) to other parties. Even so far it's actually a license jsh Social Humanities Journal, Vol. 8

No.2, November 2015. it is still associated with authority in the form of privileges granted by the state to use and utilize certain patents, trade secrets and technology.

According to Gunawan Widjaja the license is a form of licensing to utilize an intellectual property right that can be given by the licensor to the licensee so that the recipient can carry out a form of business activity, either in the form of technology or knowhow that can be used to produce selling produce or market certain (tangible) goods and those that will be used to carry out certain service activities by using the licensed Intellectual Property Rights (Gunawan Widjaj, 2001; 10-11). For this purpose, the licensee is required to provide counter-performance in the form of royalty payments, also known as license fees.

\subsection{Whereas according to Article 1 number 13 of the Patent Law.}

A license is a permit granted by a patent holder to another party based on an agreement granting rights to enjoy the economic benefits of a patent that is given protection in terms of time and certain conditions.

Whereas the Indonesian license in Indonesia is regulated in Chapter $\mathrm{V}$ of Part Three of Law No. 14 of 2001 concerning Patents, stating that: 
A compulsory license is a license to carry out patents granted based on the decision of the Directorate General on the basis of an application (article 74).

Requests for compulsory licenses can only be made on the grounds that the patent in question is not carried out or implemented not fully in Indonesia by the patent holder (article 75 paragraph (2) of Law No. 14 of 2001). Requests for compulsory licenses can also be submitted at any time after the patent or the licensee in the form and in a way that is detrimental to the interests of the community (article 75 paragraph (3) of Law No. 14 of 2001). A compulsory license may also be requested by the patent holder at any time for the reason that it is impossible to carry out the patent without violating other existing patents (article 82 paragraph (1) of Law No. 14 of 2001).

\subsection{Intellectual Property Rights as a Ownership System}

The foundation of the IPR philosophy began when he put forward the idea of appreciation for creators or inventors of their intellectual creations that were useful to society in Aristotle's politics during the fourth century $\mathrm{BC}$ (Anthony D Amanto and Doris Estelle Long, 1996; 25).
In various discussions Aristotle often criticized sharply the opinion of Hippodamus of Miletus, who submitted a proposal for the Award System(reward system) for those who contributed to making useful discoveries for the community. The proposal stated that: "if you reward the creators of useful things, you get more useful things". For this proposal, Aristotle argues that: "A such system of individual rewards may otherwise reduce social welfare A reward for revealing information to the state would give rise to fraudulent claims of discovery of success on the part of public officials "(Anthony D Amanto and Doris Estelle Long, 1996; 25).

There are two philosophical theories related to the legal presumption that IPR is a property system, the theory put forward by John Locke and Hegel. John Locke teaches the concept of property related to Human Rights (Human Righats) with his statement: "Life, Liberty and Property" (Anthony D Amanto and Doris Estelle Long, 1996; 25). Locke states that originally in the state of nature the state of security was secure and there was no positive law which divided ownership or authorization of certain people to govern others. This is a moral obligation for someone's behavior towards others. Which obligation is imposed by God and this can be seen from various reasons. But then naturalist status cannot continue to be maintained because the country does not 
have judges who can provide binding translations of natural law to resolve conflicts of interest between individuals. For that people form status civilis (state of civilized) because their authority will provide a safeguard for natural rights that are not available in naturalist status.

The Hegelian concept establishes the capacity of one's rights together with the ethics of life and the feeling of Godhead which sets minimum moral standards and at the same time prevents inconsistencies from his statement that a person has his body naturally and that it is not property. Abstract right is not from natural human entity but from free will in it and by itself, which is a conception.

abstract. Wealth is an expression of will as part of personality and it creates the requirements for further action.

Legal protection is often limited and that respect for intellectual property is bestowed on the strength of these rights and community respect that depends on the ability of thinkers and the tolerance of society to prevent imitation. According to Hegel, property as personal identification also benefits the community. The market share is the referee through individual markets trying to put down and protect selfidentity through voluntary property exchanges that reflect individual will. The community in this case has limited rights to prevent reasonable individual interests in accumulating, mastering, giving permission for its property. Community needs alone (as sunch) will not justify a person's takeover of property without proper compensation.

Thus Hegel's theory complements Locke's theory with two reasons, namely (Spyros M. Maniatis, 2002; 5): First, IPR is property that is related to works that show human intellectual capacity and creativity more than just consumption as stated by Locke. Second, Locke's interpretation of the theory that shows the logical sequence of IPRs that humans from the beginning had a body and a submissive effort to a 'no man's desert' became the beginning of Hegel's theory, that IPR is an abstract right that is a human reason to exist.

\subsection{Definition of Patent}

To understand the concept of patents and the following will be explained the understanding of both taken from the laws in Indonesia.

a. Patents under Law No. 14 of 2001

Patent: exclusive rights granted by the State to Inventors for the results of their competence in the field of technology, which for a certain period of time 
carry out the invasion by yourself or give the press an objective to other parties to implement it.

Invention: Inventor ideas that are poured into a specific problem solving activity in the field of technology can be in the form of a product or process, or an improvement or development of a product or process.

Inventor: a person who individually or several people who jointly implement an idea poured into an activity that produces an invention.

Patents are given for inventions that are new and contain inventive steps and can be applied in industry. An invention is said to contain an inventive step if the invention is something new or something that cannot be predicted beforehand according to people who have certain expertise in the field of engineering. The assessment that an invention is an unpredictable thing must be carried out with due regard to existing expertise at the time the application is submitted.

submitted. An invention is considered new if on the acceptance date, the invention is not the same as the technology disclosed previously. The patent is granted for a period of 20 (twenty) years from the Filing Date and the period cannot be extended.
The Patent Holder has the exclusive right to carry out his Patent and prohibit other parties without his consent:

a. in the case of product patents: making, using, selling, importing, renting, surrendering or providing for sale or leasing or surrender of products that are given a patent.

b. in the case of process patents: use the production process that is given a patent to make goods and other actions as referred to in letter a.

If someone wants to use the patent then they must pay royalties to the patent holder.

\section{Whereas the right in the Black's Law}

\section{Dictionary is disabled:}

The meaning of justice, means of justice, ethical correctness, or consonance with the rules of power or security are guaranteed to be under constitution, statutes or decisive law as a result of long usage ; Exclusive Right means right to exclude, other rights, and other rights, including the right to exclude another, the other shall do (exclude others) (Henry Campbell Black , 1996; 1216).

Rights are demands that can be enforced legally from someone against another party that makes the other party must act or not act (according to applicable law). Exclusive rights are the right to exclude 
parties other within a certain period of time taking into account the applicable restrictions. Soedikno Mertokusumo, stated that: "Rights are interests protected by law. Interest is the demand of individuals or groups that are expected to be fulfilled "(Sudikno Mertokusumo, 1989; 41).

Material rights that provide perfect enjoyment for the owner are called "ownership rights" which in various state laws are named

"Property right". Property (property) is defined as:

that is perculiar or proper to any person that which belongs exclusively to one; In the strict legal sense, an aggregate of rights which are guaranted or protected by goverment; the word is also commonly used to denote everything which is the subject of ownership, corporeal or incorporeal, tangible or intangible visible or invisible real or personal everything that has an exchangeable value or which goes to make up wealth or estate (Mariam Darus Badrulzaman, 45).

\subsection{Hak}

Rights are something that is right for everyone and which is exclusively owned by someone. This word is also commonly used to indicate something that is subject to physical and non- tangible ownership, tangible or intangible, visible or invisible, wealth on tangible or non-tangible objects, which can be exchanged or can increase wealth or material.

The concept of assets according to Indonesian law includes objects and legal relations to obtain these objects. In other words include objects (zaak) and engagement (verbintenis) (Van Apeldoorn, 1973; 63-71). Property is an object belonging to someone who has economic value (Abdul Kadir Muhammad, 1994; 10). Furthermore, according to article 499 Burgelijke Wetboek (BW) the understanding of objects (zaak) includes goods (good) and rights (recht). Both assets and rights attached to them are recognized and protected based on legal evidence.

\section{Whereas the definition of Property is contained in article 570 BW which states:}

\begin{abstract}
Ownership rights are the right to enjoy the usefulness of something material freely and to do something free to material.
\end{abstract}

full origin does not conflict with laws or general regulations stipulated by a power that has the right to determine and not interfere with the rights of others by not reducing the possibility of revocation of rights in the public interest based on the 
provisions of the law and with payment of compensation .

Based on these provisions, the right to property only applies to movable goods including:

1. the right to control freely;

2. the right to enjoy fully;

3. not in contravention of the law (which is extended not contrary to law) The definition of law includes laws, unwritten law, decency and

public order. It does not conflict with the law meaning that it is in accordance with the law or can be justified and accepted by the parties in the community because the use of property rights is reasonable, appropriate and appropriate. Justice, worthiness and obedience are the essence of law. According to Pitlo, there is an abuse of rights if the use of such rights is such that the loss of another person is greater than the benefits obtained by the owner who uses his property. So, the concept of freedom in property rights that does not conflict with the law, implies that mastering and enjoying property rights must not interfere with others or misuse rights that harm others (Abdul Kadir Muhammad, 1994; 38).

\subsection{The Role of the State in Realizing Healthy Competition}

State interference can not be separated from the legal politics of a country to realize the goals of the country. The objectives of the Indonesian state are: ... to advance public welfare ... which of course must be understood wisely as a policy that refers to the market economic system (market economic system).

The goal of the country according to W. Friedman. as one of the thinkers about the welfare state that the rule of law in its function in non-totalitarian society refers to a mixed economy system, namely: "to indicate the situation in which the role of government as a owner and regulator has been sufficiently large to cast doubt on the validity of capitalists and free enterprise as a result of large adjective but not sufficiently large to justify the appellation socialist "(W. Friedmann, 1971; 1).

Protection of IPR as private property rights is a crucial element of industrial process trade policy. In order to understand the symptoms and economic aspects related to trade policies and to link them to the international structure or specifically the dynamics of international economic relations, IPR protection cannot be ignored. 
In the scale of international trade, the WTO has been formed which is the result of the long journey of the GATT through a round of negotiations. GAAT itself is a multilateral agreement and only later becomes a special agency from the United Nations. GAAT negotiations began in the Atlantic Charter in 1941 which at that time after World War II was recognized as the most important requirement for maintaining world peace by arranging a ravaged economy (Philip Griffith, 1996; 2).

The Uruguay Round of GAAT does not only concern tariffs but continues to negotiate tariff barriers to include services in the negotiation agenda and include TRIPs as a field that has influence over non-tariff barriers and service trade. Although it cannot be denied that the effort to include IPR issues in the negotiating agenda is the pressure of America, which wants an agreement that provides standards for IPR law enforcement in the sense that it contains procedures for resolving disputes and strict sanctions if the participating countries do not fulfill their obligations. After going through tough negotiations because there were quite a number of problems due to difficult differences to meet, the Director General of GATT in both of them as the Trade Negotiating Committee took the initiative and on its own responsibility formulated the articles of TRIPs. This then causes the text (design) of TRIPs to be the Chairman Text or The Dunkel Draft.

TRIPs as mentioned in Annex 1C enter coherently and integrally with WTO approval. TRIPs contain the following conditions:

a. Part I General Provisions And Basic Principle (Article 1-8);

b. Part II Standards Concerning the Availability Scope and Use of Intellectual Property Rights and Control of Anti Competitive Practice in Contractual Licenses (Article 9-4);

c. Part III Enforcement of Intellectual Property (Article 41-61);

d. Part IV Acquistition and Maintenance of Intellectual Property Rights and

Related "inter-partes" procedures (Article62);

e. Part V Dispute Prevention and settlement (Article 62-64);

f. Part VI Transitional Arrangements (Article 65-67);

g. Part VII Institutional Arrangement: Final Provisions (Article 68-73). TRIPs have general and fundamental goals, namely to reduce 
distortion and things that make it difficult for progress to reduce distortions and impediments to international trade. The second objective of TRIPs is to protect private rights (to protect private property right). Member countries agree to empower IPR holders and if IPR holders fail to enforce their rights, the government can be asked to help enforce this law through existing legislation and legal institutions that enable citizens to protect themselves against HKI violations .

\subsection{Limitation of Patent Rights}

IPR as a ownership regime with the provision of exclusive rights is not unlimited. Article 30 TRIP stipulates that there are exceptions to exclusive patent rights, namely:

The best way to get the most out of the way to take part in the history of the legitimate interests of third party.

Countries may regulate exceptions to the exclusive rights covered by the patent. Provided that the exception is not without legitimate reasons contrary to the normal exploitation of the patent and does not harm the reasonable interests of the Patent Holder, and continues to take into account the interests of the third party.
One form of limiting exclusive patent rights is the rule regarding compulsory license. Compulsory licenses in this case can be given to two categories of users, namely the Government (or Government bodies or third parties authorized by the state) and other personal third parties. The difference is based on the nature of the license and not from the intended use. It is naturally very irrelevant to set requirements for licenses such as time period and royalties. The government can impose a compulsory license on special situations and conditions with exception and if there are serious reasons to justify the existence of a license mandatory. In relation to the provisions of Article 7 TRIPs and taking into account paragraph 4 of the TRIPs preamble, the balance between rights and obligations cannot be obtained through the reduction of patent holder rights without the addition of the collective interest of the wider community. This means that individual rights of patent holders must not be reduced for the benefit of other individuals, only social and collective interests can justify the imposition of licenses mandatory.

The requirement for the first mandatory license, Article 27 TRIPs implicitly implies that the government must not impose compulsory licenses based on the lack of work in the local or local area. Therefore, patent holders can import 
patented products including importing products made with a patented process. Second, the compulsory license must not be granted only for the reason that the patent holder has refused to license the third party because the essence of the patent exclusive rights is indeed to exclude a third party without his permission to exercise his rights and use his invention. To deny this right means to damage the exclusive rights of the patent in this case contrary to the objectives of the standards set in TRIPs.

So if the Patent holder is not given the right to refuse or grant the permission of another party through a licensing agreement, the mandatory license obligation is meaningless. Precisely the mandatory license rules exist because the recipient of a prospective license has previously tried to obtain a voluntary license, but was refused because it was not in accordance with the wishes of the patent holder. For this reason, third parties can request government intervention to be able to be given a compulsory license. However, this third party must endeavor to obtain a voluntary license first, before applying for a compulsory license. This party must also offer the terms of a proper agreement within a reasonable period of time and with appropriate commercial benefits. Appropriate time determined by member countries is usually 90 days or 6 months for patent holders to respond to attempts to submit this license. The specific reasons for compulsory licenses are:

a. To establish rights after a legal or administrative process that stipulates the existence of anti-competitive practices (Article $31(\mathrm{k})$ );

b. To allow exploitation of patents that cannot be exploited without violating the patents of other parties (Article 31 (1));

c. To prevent misuse of patent holder rights resulting from the implementation of other exclusive rights (Article 5A (2) and (3) Paris Convention);

d. To reduce the absence or insufficiency of the implementation of patented inventions (Article 5A (2) and (3) Paris Convention);

e. For the benefit of the community, among others, according to needs urge a country or other extreme situations or conditions or community interests that are not for commercial use (Article31 (b) TRIPs).

\section{B. CONCLUSION}

IPR as philosophical originates from the conception of John Locke and Hegel which originated from the Theory of Natural Law, which derives from morality, about what is good and what is bad. Based on the historical approach taken, it can be seen that the justification of John Locke's ontology refers to the 
rights associated with one's efforts (the Labor theory). Whereas Hegel refers to rights that are associated with personality or self-identity. IPR as a property rule is related to ownership and violation rules. The justification of IPR as personal wealth is associated with the existence of inequality in society concerning the question of distributive equality of IPRs. For this reason, the spread of IPR control as a system of wealth and ownership must be based on the principle of justice and the principles of procedural honesty and fairness. This is to prevent the tendency of IPR abuse by IPR holders. In this case state intervention is needed to organize the existing rules. At present multilaterally an international agreement has been reached through the WTO Establishment Agreement with one of its agenda TRIPs, which contains commitments, concessions and negotiations made by the signatory countries, including Indonesia to improve IPR protection to create healthy competition.

- IPR as a ownership regime with the provision of exclusive rights is not unlimited. Countries may regulate exceptions to the exclusive rights covered by the patent. Provided that the exception is not without legitimate reasons contrary to the normal exploitation of the patent and does not harm the reasonable interests of the Patent Holder, and continues to take into account the interests of the third party. One form of limiting exclusive patent rights is the rule regarding compulsory license. Compulsory licenses in this case can be given to two categories of users, namely the Government (or Government bodies or third parties authorized by the state) and other personal third parties .

\section{ACKNOWLEDGEMENT University Of Indonesia \\ University Of Mitra Indonesia \\ Telkom University \\ University Of Mellbourne \\ Saitama University}




\section{E. REFERENCE (Based APA $)$}

\section{REFERENCE (Based ISO 690 )}

[1]

\begin{tabular}{|c|c|}
\hline \multicolumn{2}{|c|}{ A. S. Putra And O. M. Febriani, } \\
\hline "Knowledge & Management \\
\hline Online A & ation \\
\hline Lampung & Province," \\
\hline Prosiding & \\
\hline Conference & fo \\
\hline Technolo & And \\
\hline
\end{tabular}

[2] A. S. Putra, O. M. Febriani, And B. Bachry, "Implementasi Genetic Fuzzy System Untuk Mengidentifikasi Hasil Curian Kendaraan Bermotor Di Polda Lampung," J. Sist. Inf. Dan Manaj. Basis Data, Vol. 1, No. 1, Pp. 21-30, 2018.

[3] O. M. Febriani And A. S. Putra, "Sistem Informasi Monitoring Inventori Barang Pada Balai Riset Standardisasi Industri Bandar Lampung," J. Inform., Vol. 13, No. 1, Pp. 90-98, 2014.

[4] Putra, Arie Setya. "2018 Artikel Struktur Data, Audit Dan Jaringan Komputer." (2018).

[5] Putra, A. S. (2018, July 17). Paperplain Fundamental Create Application With Borland Delphi 7.0 University Of Mitra Indonesia. Retrieved From Osf.Io/Pbrn9.
Putra, A. S., Aryanti, D. R., \& Hartati, I. (2018, November). Metode SAW (Simple Additive Weighting) sebagai Sistem Pendukung Keputusan Guru Berprestasi (Studi Kasus: SMK Global Surya). In Prosiding Seminar Nasional Darmajaya (Vol. 1, No. 1, pp. 85-97).

Sari, D. P., Febriani, O. M., \& Putra, A. S. (2018, November). Perancangan Sistem Informasi SDM Berprestasi pada SD Global Surya. In Prosiding Seminar Nasional Darmajaya (Vol. 1, No. 1, pp. 289-294).

Putra, A. S. (2018). Paperplain: Execution Fundamental Create Application With Borland Delphi 7.0 University Of Mitra Indonesia.

Putra, A. S., Sukri, H., \& Zuhri, K. Sistem Monitoring Realtime Jaringan Irigasi Desa (JIDES) Dengan Konsep Jaringan Sensor Nirkabel. IJEIS (Indonesian Journal of Electronics and Instrumentation Systems), 8(2), 221232.

Darmawan, A., Yuliawati, D., Marcella, O., \& Firmandala, R. (2016). Sistem Absensi dan Pelaporan Berbasis Fingerprint dan SMS Gateway. EXPLORE, 7(1).

Febriani, O. M., Wahyuni, T., \& Yusuf, S. (2017). DESIGN OF WEBSITE-BASED INFORMATION SYSTEM FOR EDOCUMENT ADMINISTRASI IN THE 


\section{QUIZ Selected Section Class}

COMMUNITY SERVICE UNIT (A Case Study at Rajabasa District). INTERNATIONAL JOURNAL OF COMPUTERS \& TECHNOLOGY, 16(7), 7010-7020.

Febriani, O. M., \& Wahyuni, T. (2017, October). PERANCANGAN SISTEM E-DOCUMENT ADMINISTRASI LOGBOOK PENELITIAN PADA UNIT LAYANAN DI BANDAR LAMPUNG. In Prosiding Seminar Nasional Darmajaya (Vol. 1, No. 1, pp. 187-194).

Febriani, O. M., \& Permadi, A. B. (2017). Implementasi Sistem Aplikasi Data Bimbingan dan Pelanggaran Siswa pada Sekolah Menengah Atas di Lampung Tengah dengan Metode Analisis dan Desain Sistem Terdistribusi (SSAD). EXPERT, 7(1).

Febriani, O. M., \& Ambarwati, L. (2015). PERANCANGAN APLIKASI PENGOLAHAN DATA PENJUALAN UKM KELANTING KHAS TELO DESA SIDOHARJO KECAMATAN JATI AGUNG KABUPATEN LAMPUNG SELATAN. Jurnal Teknologi Informasi dan Bisnis Pengabdian Masyarakat Darmajaya, 1(1), 77-95.

Febriani, O. M. (2015). Rancang Bangun Aplikasi Ecommercemenggunakan Freewebstore pada UKM Kelanting di Desa Sidoharjo Lampung Selatan. Prosiding Sembistek 2014, 1(02), 446-458. 